\title{
VOCs Levels in Indoor and Outdoor Residential Homes in Helwan, Egypt
}

Alia Abd El-Shakour, A. S. El-Ebiarie*, Y.H. Ibrahim, A.E. Abdel Moniem* and Asmaa M. El-Mekawy

Air Pollution Department, National Research Centre, 33Bohouth St. Dokki,Giza and ${ }^{*}$ Zoology and Entomology Department, Helwan University, Cairo, Egypt.

\begin{abstract}
VOCs measurements in indoor and outdoor residential homes, located in four residential sectors of Helwan city, south Cairo, Egypt, were conducted during 2010-2011. VOCs samples were collected according to a standard method developed by NIOSH using activated charcoal tubes and analyzed by GC/FID. The highest ambient VOCs level was determined in site 2 (Helwan city center/commercial/residential area) reaching $102.63 \mu \mathrm{g} / \mathrm{m}^{3}$. The highest VOCs levels were recorded in winter and autumn seasons, while the lowest values were found in summer. The maximum VOCs levels in indoor air were measured at site 1 (Helwan city center/residential area) reaching $77.3 \mu \mathrm{g} / \mathrm{m}^{3}$. The highest indoor VOCs levels were observed in winter, while the lowest values were found in summer. Indoor annual mean concentration of total VOCs was higher than outdoor (I/O ratio) at sites 1 and 4 (Torra/ popular residential area), more than 1.5 which indicates the role of both indoor and outdoor sources at these sites. I/O ratio for annual mean concentration for individual VOCs was higher than 1 for most VOCs which indicates that the air inside Egyptian homes is affected by both indoor and outdoor sources. For some VOCs, I/O ratio was higher than 10 (e.g. Toluene and 1,3,5 Trimethylbenzene at site 1) which indicates dominant indoor sources for these pollutants at site 1 . This study shows the impact of indoor and outdoor sources on air inside homes and indicates that the high levels of VOCs in indoor air are sufficient to represent a degree of risk to the residence population .
\end{abstract}

High proliferation of urban life style has given rise to indoor air pollution and thereby has become a public concern in the past few decades. Indoor air pollution may has a greater impact than outdoor pollution because people spend about $90 \%$ of their time within enclosed environments (living, working and studying) such as homes and workplaces, which means that ambient air concentrations may not reflect accurate personal exposures ${ }^{(1-8)}$. This evaluation is more pronounced on inactive people (e.g. old age persons, infants, children and the disabled) ${ }^{(9)}$.

Volatile organic compounds (VOCs) are among the most abundant chemical pollutants in the indoor air ${ }^{(10-12)}$. VOCs are a group of chemicals that have 
attracted particular scientific attention due to the number and diversity of their sources as well as their potential harmful effects on human health ${ }^{(13-15)}$. Some VOCs are associated with sick building syndrome (SBS) including mucous membrane irritation, headache, fatigue, dizziness, and vertigo ${ }^{(16-18,7)}$. Others are known carcinogens (e.g., formaldehyde, benzene, acrolein) ${ }^{(19)}$. Concentrations of many VOCs are consistently higher indoors (up to ten times higher) than outdoors $^{(7)}$.

This study is designed to characterize the distribution and variability of 13 VOCs in indoor and outdoor residential homes located in four residential sectors of Helwan city.

\section{Materials and Methods}

\section{Area under investigation}

Helwan is a city in Egypt on the bank of the Nile river. It is situated about $24 \mathrm{~km}$ south east of Cairo city. It had a population of 643,327 at the 2006 population $^{(20)}$. Helwan is a residential area surrounded from its north and south by industrial activities; about 32 establishments for manufacturing of cement, automobiles, iron and steel, lead and zinc smelting, foundries, ceramics, chemicals, coke, fertilizers, spinning and weaving, starch, and other miscellaneous activities. In addition, there are two big power stations, one in the north and the other in the south of Helwan city. Helwan is impacted by emissions from nearby industrial activities.

\section{Site characterization and sampling strategy}

Homes were chosen in order to adequately cover the various sections and activities taking place in the area under investigation. Participants were recruited on a voluntarily basis. According to building surroundings and road configuration, four residential buildings in Helwan city were selected, and represented as sites $1,2,3$ and 4 as shown in Table 1 and Fig. 1. Table 2 represents Questionnaire items defining the factors affecting presence of pollutants and their levels at homes under investigation.

\section{Sampling of VOCs}

Thirteen VOCs (Benzene (B), Toluene (T), Ethylbenzene (E), Styrene (S), Bromobenzen (BrB), m-Xylene (m-X), 1,3,5-Trimethylbenzene (1,3,5 TMB), 1,2,4-Trimethylbenzene (1,2,4 TMB), Isopropyltoluene (IPT), n- Butylbenzen (nBB), 1,2.4 Trichlorobenzen (1,2,4 TCB), 1,2.3 Trichlorobenzen (1,2,3 TCB) and Naphthalene (NAP)) were detected in all sites under investigation.

Sampling was carried out at all investigated sites in both indoor and outdoor, simultaneously. Two daytime samples were collected monthly at each of the sampling locations (indoor and outdoor, simultaneously), starting from September 2010 to August 2011 (96 samples per year).Indoor samples were collected at about 1.5 meters height from the floor of living room, while outdoor 
samples were taken at a height of $1.5-2 \mathrm{~m}$ in the buildings balconies and at least $1 \mathrm{~m}$ away from the wall. The heights of the balconies were 4-10 m from street ground level.

VOCs samples were collected according to a standard method developed by NIOSH using activated charcoal tubes (ORBOTM-32 activated coconut charcoal (20/40)) ${ }^{(21)}$. The collecting tubes (Supelco, Inc., Bellefonte, PA) contained $150 \mathrm{mg}$ of coconut charcoal sub-divided into two portions of $100 \mathrm{mg}$ and $50 \mathrm{mg}$; the front portion of $100 \mathrm{mg}$ was used to collect the VOCs, while the $50 \mathrm{mg}$ backup section was intended to determine if solvent breakthrough occurred from the front section. The breakthrough volume is the volume of gaseous sample that can be drawn through a sample tube before an analyte is eluted from the tube. Air was drawn through the charcoal tubes, using a pump calibrated to draw $0.20 \mathrm{~L} / \mathrm{min}$. After sampling time, the charcoal tube was removed from the sampling train and two open sides were tightly closed using special caps to avoid any desorption. During the sampling procedure, one charcoal tube was opened at the sample site and then the ends capped, which served as a blank. The samples and blanks tubes were put into special plastic bags that were tightly closed and kept at $-10{ }^{\circ} \mathrm{C}$ in a freezer until processed, not more than 15 days.

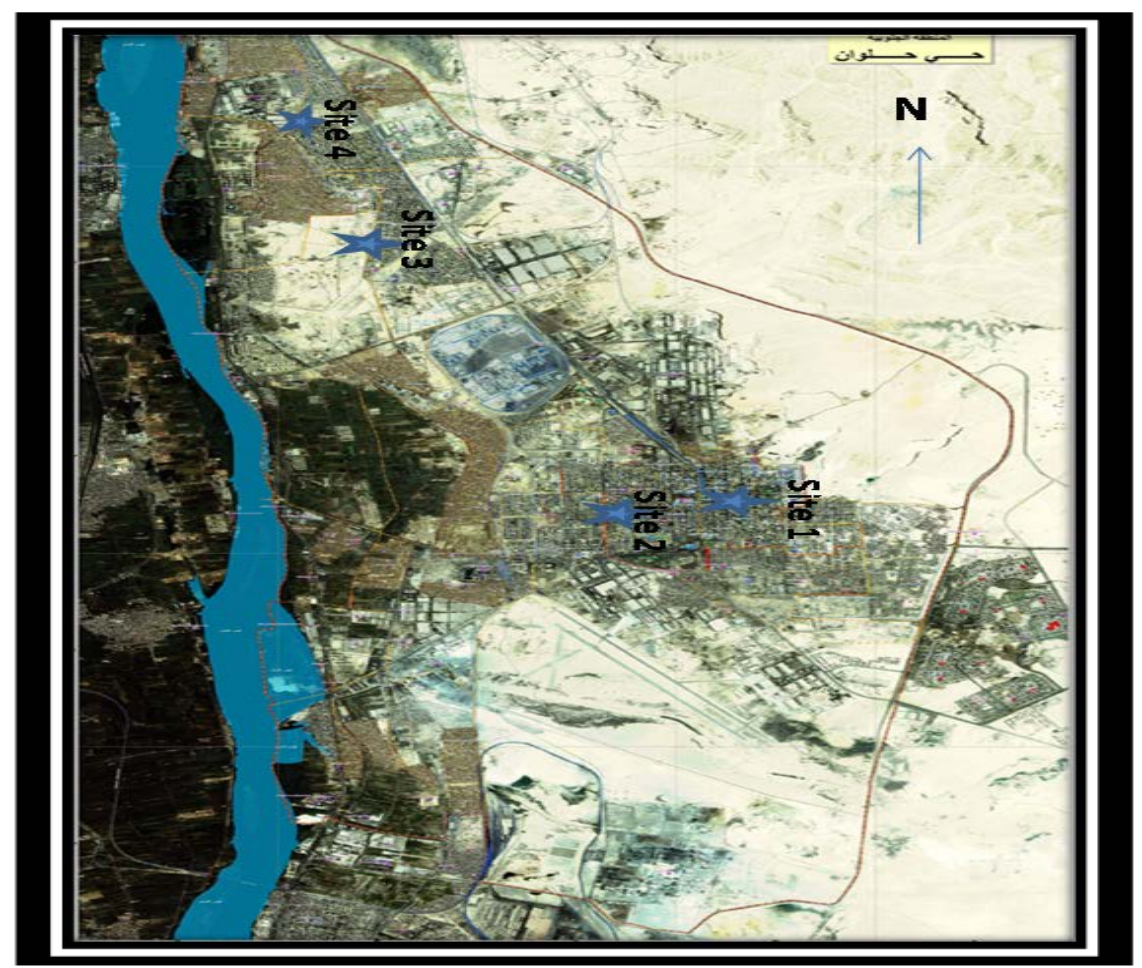

Fig. 1. Map of Helwan city showing sampling sites.

Egypt. J. Chem. 58, No. 2 (2015) 
TABLE 1. Description of sampling locations and characteristics.

\begin{tabular}{|c|c|c|}
\hline Site & & Description \\
\hline Site 1 & $\star$ & $\begin{array}{l}\text { Located in Helwan city center } \\
\text { A flat in the fourth floor with about } 16 \mathrm{~m} \text { high from ground } \\
\text { level. } \\
\text { With medium road traffic. } \\
\text { Was built in } 1975 . \\
\text { Downwind of Cairo city. } \\
\text { Represents residential area. }\end{array}$ \\
\hline Site 2 & 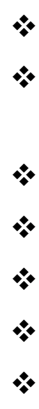 & $\begin{array}{l}\text { Located in Helwan city center. } \\
\text { A flat in the second floor with about } 5 \mathrm{~m} \text { high from ground } \\
\text { level. } \\
\text { Adjacent to a busy road with heavy traffic. } \\
\text { Was built in } 1972 \text {. } \\
\text { Downwind of Cairo city. } \\
\text { Was about } 900 \mathrm{~m} \text { away from site } 1 . \\
\text { Represents commercial /residential area with high traffic. }\end{array}$ \\
\hline Site 3 & * & $\begin{array}{l}\text { Located in Wady Hoff at the north of Helwan city. } \\
\text { A flat in the second floor with about } 5 \mathrm{~m} \text { high from ground } \\
\text { level. } \\
\text { There were no main traffic roads, but the relatively narrow } \\
\text { lanes for residents and private cars in and out. } \\
\text { Was built in } 1989 \text {. } \\
\text { Downwind of Cairo city. } \\
\text { Represents residential area with light traffic. }\end{array}$ \\
\hline Site 4 & $*$ & $\begin{array}{l}\text { Located in Torra (cement factory located close to } \\
\text { residential area) at the northern part of Helwan city. } \\
\text { A flat in the first floor. } \\
\text { Was built in } 1985 \text {. } \\
\text { Downwind of Cairo city. } \\
\text { Represents a popular residential area (buildings are close to } \\
\text { each other). }\end{array}$ \\
\hline
\end{tabular}


TABLE 2. Questionnaire items defining the factors affecting presence of pollutants and their levels.

\begin{tabular}{|c|c|c|c|c|}
\hline Questions & Site 1 & Site 2 & Site 3 & Site 4 \\
\hline Cooking (hour) & 4 & 2 & 3 & 6 \\
\hline Using ventilation fan & Yes & No & Yes & Yes \\
\hline Type of fuel & natural gas & natural gas & natural gas & *LF \\
\hline Presence of smokers & Yes (1) & No & No & No \\
\hline $\begin{array}{c}\text { Floor type of living } \\
\text { room }\end{array}$ & Carpet & Carpet & Carpet & Carpet \\
\hline $\begin{array}{c}\text { Use of air conditioner } \\
\text { Yuration of opening } \\
\text { windows in living room } \\
\text { (hour) }\end{array}$ & $\begin{array}{c}\text { room) } \\
\text { Yed }\end{array}$ & No & $\begin{array}{c}\text { Yes (only } \\
\text { bed room) }\end{array}$ & No \\
\hline Use of pesticides & Few & No & No & No \\
\hline
\end{tabular}

* Liquefied Gas

\section{Extraction of VOCs}

Before analysis, all samples and blanks were taken from the freezer, contents of both sections of the adsorbing tubes were transferred to glass test tubes containing $2.00 \mathrm{ml}$ of distilled carbon disulfide $\left(\mathrm{CS}_{2}\right)$. The tubes were shaken using a mechanical shaker for half an hour and were left to settle for at least $1 \mathrm{hr}$ to obtain the final sample solution. $2 \mathrm{ml}$ aliquot was then withdrawn from the samples, including the blank and injected into a gas chromatography (GC).

\section{Analysis of VOCs}

Qualitative and quantitative determination of individual VOCs were undertaken using Hewlett-Packard gas chromatography (GC) (Model HP6890), fitted with a flame ionization detector (FID). A HP-5 $(30 \mathrm{~m} \times 320 \mu \mathrm{m} \times 0.25 \mu \mathrm{m})$ capillary column was used with hydrogen as carrier gas and temperature programming from $30^{\circ} \mathrm{C}(5 \mathrm{~min})$ to $250{ }^{\circ} \mathrm{C}$ at $10^{\circ} \mathrm{C} \mathrm{min}^{-1}$. The instrument was checked on daily basis based on the drift in retention times and responses of selected compounds in the standard calibration mixture injection. The concentrations of the target VOC species were quantified by an external standard calibration. The peaks in the chromatogram were identified by comparing retention times (from GC chromatogram) with those of standards and they were quantified by comparing the integrated peak area with that of the nearest standard. The concentrations of individual VOCs were calculated and expressed in $\mu \mathrm{g} / \mathrm{m}^{3}$. GC was calibrated with a diluted standard solution of 13 VOCs mixture compounds (2000 $\mu \mathrm{g} / \mathrm{ml}$ for each) (Supleco, Inc., Bellefonte, PA). Standard solution was prepared by injection of aliquot portion of the standard into $2 \mathrm{ml}$ of the same distilled carbon disulfide $\left(\mathrm{CS}_{2}\right)$ as used for the 
sample vials. The detection limit of each compound was calculated from the data of duplicate measurements of low concentration samples and observed from their standard deviation. The method detection limits ranged from 0.02 to $0.2 \mu \mathrm{g} / \mathrm{m}^{3}$ for the target VOCs.

Quality assurance and quality control (QA/QC)

The quality assurance and quality control (QA/QC) procedure included laboratory and field blanks, parallel samples and duplicate measurements of samples. Five laboratory blanks and five field blanks were tested with no significant contamination found for any of target VOCs. The VOCs recovery after extraction with $\mathrm{CS}_{2}$ was determined by injecting a known amount of the compounds selected for study directly onto the $100 \mathrm{mg}$ portion of charcoal in five unused tubes. The sealed vials containing the charcoal were allowed to stand overnight to ensure complete absorption of the VOCs onto the charcoal. A parallel blank of $100 \mathrm{mg}$ charcoal was handled in the same manner except that no compound was added to it. The $100 \mathrm{mg}$ portion of charcoal was then removed and placed in a septum sealed vial for analyses as above.

\section{Results and Discussion}

\section{Outdoor VOCs}

Concentration of individual VOCs

Table 3 shows a comparison between annual mean concentration of individual VOCs in all investigated sites in this study and in other literatures. From this table it can be noticed that the most abundant VOCs in Helwan city were Benzene $>$ m-Xylene $>$ Ethylbenzene $>$ Bromobenzene $>1,2.4$ Trichlorobenzen $>$ Styrene.

Benzene concentration exceeded the level of other countries, for example it is about eleven times that recorded in Brisbane, Australia ${ }^{(22)}$; nine times that in Eskişehir, Turkey ${ }^{(7)}$; and about four times the concentration recorded in Northern Spain ${ }^{(23)}$. Benzene is a carcinogenic compound causing leukaemia. The WHO has estimated that a life time exposure of $1 \mu \mathrm{g} / \mathrm{m}^{3}$ of benzene leads to about six cases of leukaemia per million inhabitants ${ }^{(4)}$. According to EC Directive the annual mean benzene concentrations in ambient air must not exceed $5 \mu \mathrm{g} / \mathrm{m}^{3(24)}$. The annual mean concentration of Benzene recorded in the recent study is more than twice this limit.

Similarly, m-Xylene concentration is about eleven times that recorded in Brisbane, Australia ${ }^{(22)}$; and about 18 times that recorded in Eskişehir, Turkey ${ }^{(7)}$; and about twice the concentration recorded in Northern Spain ${ }^{(23)}$.

Furthermore, Ethylbenzene concentration is highly exceeding the concentration recorded in previous studies, it is about 26 times that recorded in Brisbane, Australia $^{(22)}$; and about 30 times that recorded by in Eskişehir, Turkey ${ }^{(7)}$; and about 3 times the concentration recorded in Northern Spain ${ }^{(23)}$.

Egypt. J. Chem. 58, No. 2 (2015) 


\section{Concentration of total VOCs}

The maximum concentration of total VOCs was found at site 2 (Fig. 2) reaching $102.63 \mu \mathrm{g} / \mathrm{m}^{3}$. It is about 8 times the concentration $\left(12.85 \mu \mathrm{g} / \mathrm{m}^{3}\right)$ recorded in southeast Michigan, USA ${ }^{(25)}$; and about 10, 3 and 3.7 times the geometric mean concentration reported in summer and winter in Japan and in China, respectively ${ }^{(26)}$. Moreover, this concentration is more than the mean concentration measured for outdoor air of Brisbane, Australia $\left(5 \mu \mathrm{g} / \mathrm{m}^{3}\right)^{(22)}$. High concentration at site 2 may be due to the impact of industrial activities on the air. Elevated VOCs concentrations have been found near large industrial facilities and complexes $^{(27)}$. The higher concentration of VOCs may be also due to the impact of traffic emissions and fuel evaporations at this site. The increase in traffic density increases both exhaust and vehicle evaporative emission. VOCs emissions could not only be resulted from the industrial source but also be affected by surrounding traffic sources ${ }^{(28)}$. In addition to urbanization/ industrialization and seasons, proximity to traffic can also strongly affect VOC concentrations, especially for aromatic compounds ${ }^{(29)}$.

TABLE 3. Comparison between annual mean concentration of individual outdoor VOCs $\left(\mu \mathrm{g} / \mathrm{m}^{3}\right)$ in the present study and in other literatures.

\begin{tabular}{|c|c|c|c|c|c|c|}
\hline & & (USA) & $\underset{(22)}{\text { (Australia) }}$ & $\underset{(7)}{\text { (Turkey) }}$ & $\underset{(23)}{(\text { Spain) }}$ & $\begin{array}{c}\text { Present } \\
\text { study } \\
\text { annual mean } \\
\text { concentratin } \\
\text { in all sites } \\
\end{array}$ \\
\hline 1 & Benzene & 1.13 & 0.9 & 1.23 & 2.84 & 11.19 \\
\hline 2 & Toluene & 2.61 & 2.3 & 6.11 & 13.26 & 3.24 \\
\hline 3 & Ethylbenzene & 0.52 & 0.3 & 0.26 & 2.15 & 7.84 \\
\hline 4 & m-Xylene & 1.98 & 0.8 & 0.47 & 3.38 & 8.70 \\
\hline 5 & Styrene & 0.04 & 0.1 & - & - & 3.88 \\
\hline 6 & Bromobenzene & - & - & - & - & 4.70 \\
\hline 7 & $\begin{array}{c}1,3,5 \\
\text { Trimethylbenzene }\end{array}$ & 0.23 & - & - & - & 1.78 \\
\hline 8 & $\begin{array}{c}1,2,4 \\
\text { Trimethylbenzene }\end{array}$ & 0.66 & - & - & - & 1.81 \\
\hline 9 & $\begin{array}{c}\text { m- } \\
\text { Isopropyltoluene }\end{array}$ & - & - & - & - & 2.34 \\
\hline 10 & n- Butylbenzene & 0.01 & - & - & - & 1.00 \\
\hline 11 & $\begin{array}{c}1,2,4 \\
\text { Trichlorobenzene }\end{array}$ & - & - & - & - & 4.08 \\
\hline 12 & Naphthalene & 0.28 & 0.1 & - & - & 3.69 \\
\hline 13 & $\begin{array}{c}1,2,3 \\
\text { Trichlorobenzene }\end{array}$ & - & - & - & - & 3.49 \\
\hline
\end{tabular}

Egypt. J. Chem. 58, No. 2 (2015) 


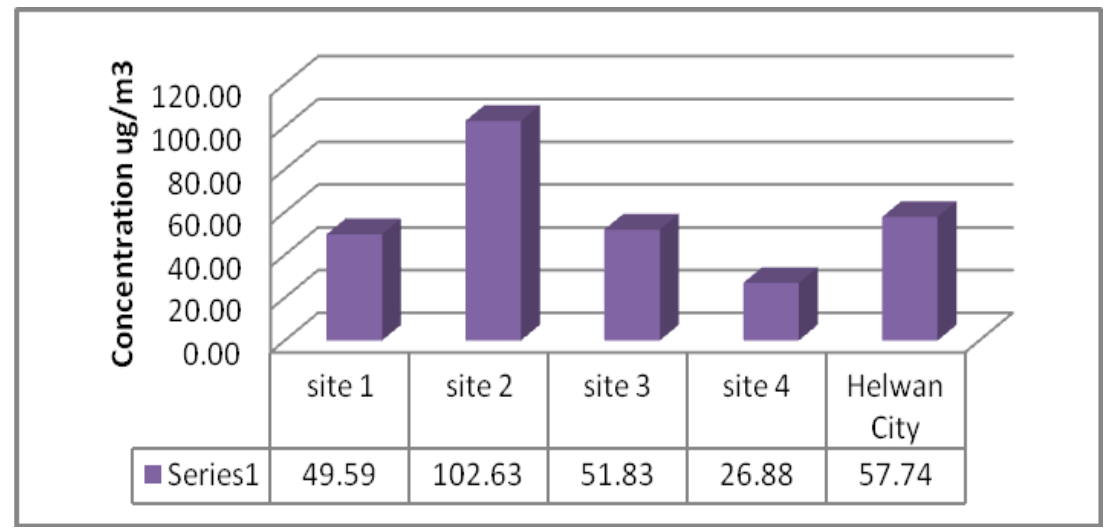

Fig. 2. Annual mean concentrations of total volatile organic compounds (VOCs) $\left(\mu \mathrm{g} / \mathrm{m}^{3}\right)$ in outdoor air at sites under investigation and over Helwan city.

\section{Seasonal variation of VOCs in outdoor air}

Figure 3 shows the seasonal mean concentration of VOCs at the investigated sites. It can be noticed from these figures that, the mean concentrations of total VOCs were varied seasonally as the highest VOCs levels were measured in winter and autumn while the lowest value was recorded in summer almost at all sites under investigation. This is in agreement with other studies ${ }^{(23,30-34)}$. The highest VOCs levels during the winter season may be attributed to an increase in the emission of VOCs, due to the use of fuel during cold season, beside higher atmospheric stability, which lead to increase the accumulation of VOCs in the atmosphere during winter, in addition to lower temperature, lower solar radiation and lower photochemical reactions during that season. Meanwhile, VOC removal is faster in summer than in winter as more sunlight and higher temperatures increase the chemical removal reaction rates, especially by $\mathrm{OH}$ radicals ${ }^{(23)}$, as well as the low atmospheric stability and higher atmospheric dispersion during summer decrease VOCs ${ }^{(35)}$.

\section{BTEX concentration ratio}

VOCs concentration ratios have been taken as an indicator to compare the BTEX emission sources ${ }^{(34,36,37)}$. Because of the varying reaction rates of VOCs with hydroxyl radical ( $\mathrm{OH}$. ), these ratios provide information about the VOCs sources. The abundance of highly reactive VOCs species usually decreases in daylight time due to photochemical reactions. On the other hand, the abundance of relatively less reactive species gradually increases during daylight time due to accumulation ${ }^{(34)}$. So that, they are used as indicators of the age of the air mass and tracers for emission sources. Evaluation of benzene/toluene (B/T), toluene/benzene (T/B), m-xylene/benzene ( $\mathrm{m}-\mathrm{X} / \mathrm{B})$, and $\mathrm{m}$-xylene/ethylbenzene $(\mathrm{m}-\mathrm{X} / \mathrm{E})$ concentration ratios is useful for characterizing the distance of vehicular emission sources and for estimating the photochemical age of the air mass ${ }^{(38,39)}$.

Egypt. J. Chem. 58, No. 2 (2015) 


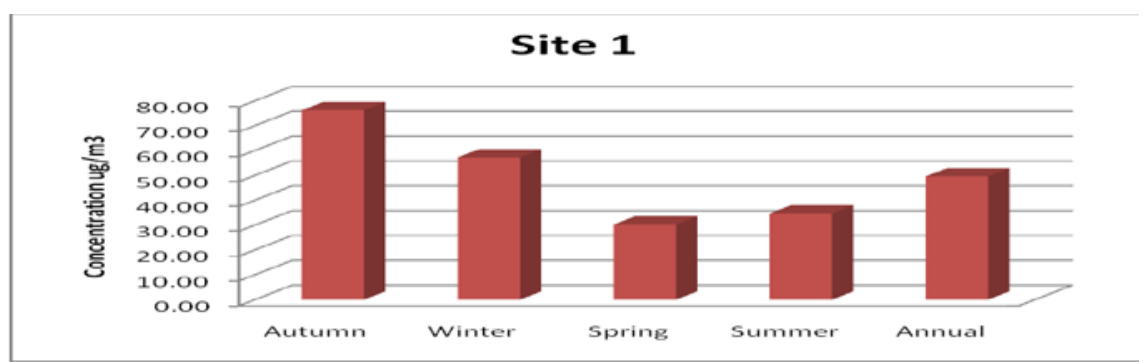

A

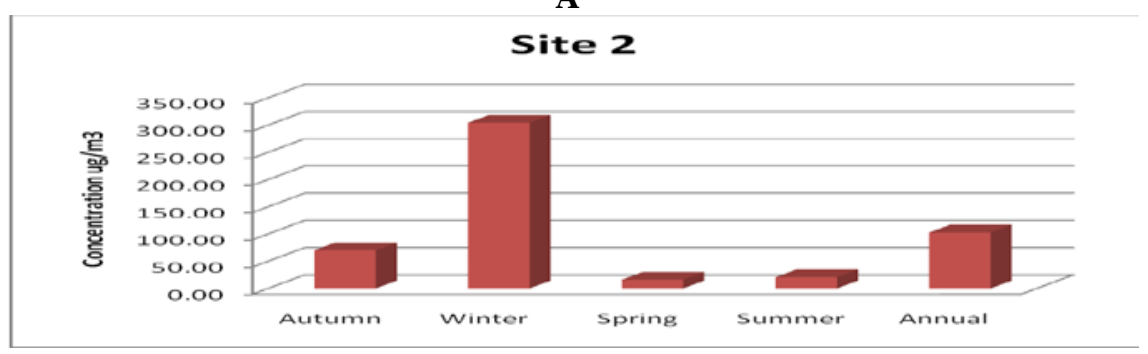

B

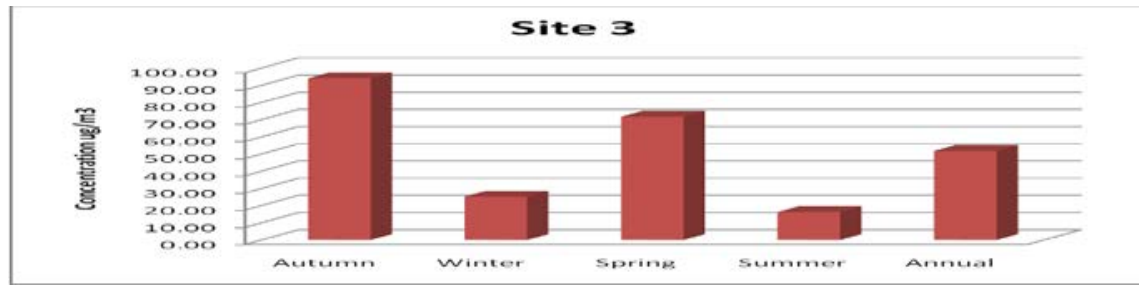

C

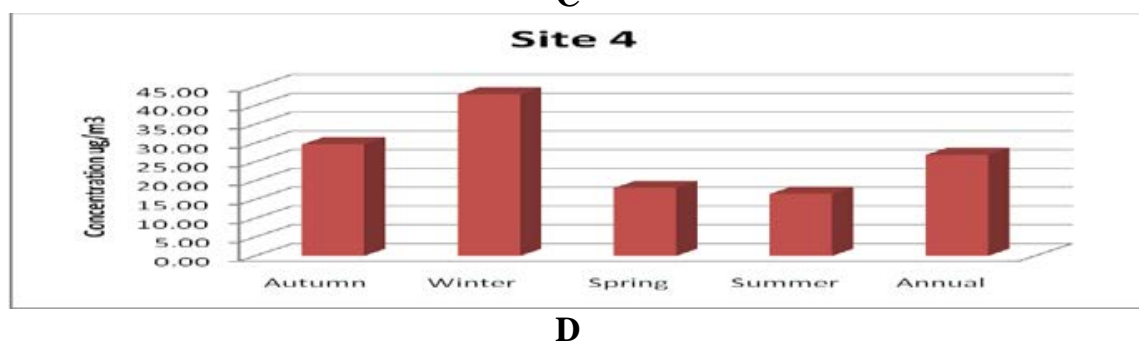

Fig.3. Seasonal and annual mean concentrations of total volatile organic compounds (VOCs) $\left(\mu \mathrm{g} / \mathrm{m}^{3}\right)$ in outdoor air of sites under investigation.

Table 4 shows a comparison between BTEX ratios in this study and those recorded in other studies. The maximum annual mean concentration ratios of (T/B) and (m-X/B) were found to be at site 1 followed by site 2, while the maximum $(\mathrm{m}-\mathrm{X} / \mathrm{E})$ ratios were found at site 3 followed by site 2 . Site 2 is suffering from existence of an intense traffic, so higher concentration ratios of $(\mathrm{T} / \mathrm{B})$ and $(\mathrm{m}-\mathrm{X} / \mathrm{B})$ may be due to traffic emission, this is in agreement with other studies ${ }^{(38,39)}$. 
TABLE 4. Comparison between outdoor BTEX ratios in this study and in other studies.

\begin{tabular}{|c|c|c|c|c|c|}
\hline \multirow{2}{*}{ Country } & $\begin{array}{c}\text { Area } \\
\text { characteristic }\end{array}$ & \multicolumn{3}{|c|}{ Ratio } & Reference \\
\hline & & T/B & $\mathrm{m}-\mathrm{X} / \mathbf{B}$ & $\mathrm{m}-\mathrm{X} / \mathbf{E B}$ & \\
\hline Egypt, Helwan & Site 1 & 0.55 & 3.12 & 0.76 & Present study \\
\hline Egypt, Helwan & Site 2 & 0.52 & 1.83 & 1.15 & Present study \\
\hline Egypt, Helwan & Site 3 & 0.19 & 0.25 & 2.35 & Present study \\
\hline Egypt, Helwan & Site 4 & 0.23 & 0.35 & 1.14 & Present study \\
\hline Japan & Industrial & 4.5 & 2.7 & 1.24 & $\mathbf{( 3 4 )}$ \\
\hline Japan & Urban & 4.8 & 1.9 & 1.13 & (34) \\
\hline Taiwan & Urban & 9.49 & 1.11 & 0.6 & (28) \\
\hline Taiwan & Industrial & 14.2 & 0.92 & 0.38 & (28) \\
\hline Taiwan & Industrial & 2.3 & 4.05 & 1.3 & (40) \\
\hline Japan & summer Industrial & 7.7 & 1.61 & 1.16 & (41) \\
\hline Japan & winter Industrial & 5.74 & 1.15 & 0.94 & (41) \\
\hline Italy & Industrial & 3.6 & 1.1 & NA & (42) \\
\hline China & Urban & 1.27 & 1.17 & 4.68 & (43) \\
\hline Turkey & Urban & 1.59 & 1.09 & 2.22 & (44) \\
\hline
\end{tabular}

\section{BTEX correlations}

Table 5 shows correlation coefficients (r) between individual outdoor air BTEX at sites under investigation. From this table it can be seen that there was a positive significant correlations $(\mathrm{p}<0.001)$ at site 1 between the concentrations of $\mathrm{B}$ and $\mathrm{T}$ and $\mathrm{E}$, and for $\mathrm{T}$ with E. Site 2 showed a significant positive correlations between the concentrations of all of BTEX with each other except for B, which suggest that all measured BTEX at site 2 (except B) are originated from similar sources, i.e. traffic emissions. Benzene content is minor compared with TEX in the petrol fuel; therefore, the evaporation of benzene to the atmosphere from vehicular is the lowest ${ }^{(23,35,45)}$. Site 3 showed a significant positive correlations $(\mathrm{p}<0.001)$ between the concentrations of $\mathrm{B}$ with $\mathrm{T}$ and with $\mathrm{E}$, and for T with E. Site 4 showed significant positive correlations $(\mathrm{p}<0.001)$ between the concentrations of $\mathrm{E}$ with $\mathrm{T}$ and with $\mathrm{m}-\mathrm{X}$ which may indicate that they are originating from the same source (vehicular emission).

Egypt. J. Chem. 58, No. 2 (2015) 
TABLE 5. Correlation coefficients ( $r$ ) between individual outdoor BTEX at sites under investigation.

\begin{tabular}{|c|c|c|c|c|}
\hline & Benzene & Toluene & Ethyl benzene & $\begin{array}{c}\text { m- } \\
\text { Xylene }\end{array}$ \\
\hline \multicolumn{5}{|c|}{ Site $1(\mathrm{~N}=12)$} \\
\hline B & 1 & & & \\
\hline B & 1 & & & \\
\hline $\mathbf{T}$ & $0.98 *$ & 1 & & \\
\hline $\mathbf{E}$ & $0.97 *$ & $0.93 *$ & 1 & \\
\hline $\mathbf{m}-\mathbf{X}$ & -0.37 & -0.49 & -0.14 & 1 \\
\hline \multicolumn{5}{|c|}{ Site $2(N=12)$} \\
\hline B & 1 & & & \\
\hline $\mathbf{T}$ & 0.50 & 1 & & \\
\hline $\mathbf{E}$ & 0.27 & $0.97^{*}$ & 1 & \\
\hline \multicolumn{4}{|c|}{ Site $3(N=12)$} & 1 \\
\hline B & 1 & & & \\
\hline $\mathbf{T}$ & $0.96 *$ & 1 & & \\
\hline $\mathbf{E}$ & $0.75^{*}$ & $0.90 *$ & 1 & \\
\hline \multicolumn{5}{|c|}{ Site $4(N=12)$} \\
\hline B & 1 & & & \\
\hline $\mathbf{T}$ & -0.46 & 1 & & \\
\hline $\mathbf{E}$ & 0.17 & $0.79 *$ & 1 & \\
\hline $\mathbf{m}-\mathbf{X}$ & 0.65 & 0.32 & $0.75 *$ & 1 \\
\hline
\end{tabular}

$\mathrm{N}$ : number of samples in statistical analysis.

*Significant $(\mathrm{p}<0.001)$

Difference in concentration of VOCs in ambient air of the investigated sites

Table 6 shows the difference in concentration of VOCs in ambient air of the investigated sites (between sites). As seen from this table, there was significant difference between site 2 and sites 1,3 and 4 , also there was significant difference between site 2 and site 4 .

Table 7 shows difference in concentration of VOCs between seasons in ambient air of the investigated sites, there was significant difference between autumn and spring at site 1 , while there was significant difference between autumn and winter and all other seasons at site 2, also there was significant difference between autumn season and winter and summer seasons at site 3 , while site 4 showed significant difference between autumn and spring and summer seasons. 
TABLE 6. Difference in concentration of VOCs in ambient air of the investigated sites (between sites).

\begin{tabular}{|c|c|c|c|c|}
\hline & site 1 & site 2 & site 3 & site 4 \\
\hline site 2 & $0.01^{* *}$ & 0.5 & & \\
\hline site 3 & 0.4 & $0.04^{*}$ & 0.5 & \\
\hline site 4 & $0.06^{*}$ & $0.0003^{* * *}$ & 0.1 & 0.5 \\
\hline site 4 & $0.06^{*}$ & $0.0003^{* * *}$ & 0.1 & 0.5 \\
\hline
\end{tabular}

* $\quad$ Significant at $\mathrm{P}<0.05$

** $\quad$ Significant at $\mathrm{P}<0.01$

*** Significant at $\mathrm{P}<0.005$

TABLE 7. Difference in concentration of VOCs in ambient air of the investigated sites (between seasons) .

\begin{tabular}{|c|c|c|c|c|}
\hline & Autumn & Winter & Spring & Summer \\
\hline Autumn & 0.5 & & & \\
\hline Winter & 0.3 & 0.5 & & \\
\hline Spring & $0.09 *$ & 0.1 & 0.5 & \\
\hline Summer & 0.1 & 0.2 & 0.4 & 0.5 \\
\hline
\end{tabular}

Site 1

\begin{tabular}{|c|c|c|c|c|}
\hline & Autumn & Winter & Spring & Summer \\
\hline Autumn & 0.5 & & & \\
\hline Winter & $0.002^{* * *}$ & 0.5 & & \\
\hline Spring & $0.01 * *$ & $0.0002^{* * *}$ & 0.5 & \\
\hline Summer & $0.02^{*}$ & $0.0002^{* * *}$ & 0.3 & 0.5 \\
\hline
\end{tabular}

Site 2

\begin{tabular}{|c|c|c|c|c|}
\hline & Autumn & Winter & Spring & Summer \\
\hline Autumn & 0.5 & & & \\
\hline Winter & $0.03^{*}$ & 0.5 & & \\
\hline Spring & 0.35 & 0.18 & 0.5 & \\
\hline Summer & $0.01^{* *}$ & 0.27 & 0.13 & 0.5 \\
\hline
\end{tabular}

Site 3

\begin{tabular}{|c|c|c|c|c|}
\hline & Autumn & Winter & Spring & Summer \\
\hline Autumn & 0.5 & & & \\
\hline Winter & 0.26 & 0.5 & & \\
\hline Spring & $0.09^{*}$ & 0.11 & 0.5 & \\
\hline Summer & $0.09^{*}$ & 0.10 & 0.43 & 0.5 \\
\hline
\end{tabular}

Site 4 


\section{Indoor VOCs}

Concentration of individual VOCs

Table 8 shows a comparison between annual mean concentration of individual indoor VOCs in all investigated sites and other literatures. The most abundant mean concentration of VOCs compounds over sites under investigation were $\mathrm{m}$-Xylene $>$ Benzene $>$ Ethylbenzene $>$ Toluene.

Annual mean concentration of indoor Benzene was more than twice the concentration reported by $\mathrm{Jia}{ }^{(25)}$, and about three times that recorded by Hamidin and Demirel ${ }^{(22,7)}$.

Annual mean concentration of benzene exceeded the EC Directive ${ }^{(24)}$ for annual mean benzene concentration in ambient air $\left(5 \mu \mathrm{g} / \mathrm{m}^{3}\right)$. Annual mean concentration of benzene is considered to be high since there is no safe level of exposure can be recommended and the unit risk of leukemia per $1 \mu \mathrm{g} / \mathrm{m}^{3}$ air concentration is $6 \times 10^{-6(4)}$. The concentrations of airborne benzene associated with an excess lifetime risk of $1 / 10000,1 / 100000$ and $1 / 1000000$ are $17,1.7$ and $0.17 \mu \mathrm{g} / \mathrm{m}^{3}$, respectively as suggested by WHO (4). As benzene concentration in this study was $7.3 \mu \mathrm{g} / \mathrm{m}^{3}$, the excess lifetime risk expected in the investigated study is over $1 / 100000$.

Indoor benzene is associated with human activities such as cleaning, painting, the use of consumer products, mosquito repellents, photocopying and printing, the storage and use of solvents, and smoking tobacco ${ }^{(4,16,33,46-48)}$.

Similar to benzene m-Xylene annual mean concentration in indoor air is more than that reported by Jia ${ }^{(25)}$, and more than twice that recorded by Hamidin ${ }^{(22)}$; about eight times concentration reported by Demirel ${ }^{(7)}$ and about 21 times concentration measured by Maisey ${ }^{(49)}$ (Table 6).

Moreover, Ethylbenzene indoor annual mean concentration is more than three times that recorded by Jia and Hamidin ${ }^{(25,22)}$; about nine times concentration measured by Demirel ${ }^{(7)}$ and about 34 times concentration measured by Maisey ${ }^{(49)}$.

\section{Concentration of Total VOCs}

The highest annual mean concentration of total VOCs in indoor air was detected at site $1\left(77.3 \mu \mathrm{g} / \mathrm{m}^{3}\right)$ as shown in Fig. 4 . The maximum concentration at site 1 may be due to the use of incense and pesticides besides opening of windows for long time daily. Indoor concentrations are also affected by climatic conditions and air exchange rate due to forced or natural ventilation ${ }^{(4)}$. This recorded concentration is about twice the median concentration of VOCs measured by Maisey ${ }^{(49)}$ in Western Australia $\left(38.1 \mu \mathrm{g} / \mathrm{m}^{3}\right)$; about three times the maximum TVOCs in indoor $0.5-22.4 \mu \mathrm{g} / \mathrm{m}^{3}$ recorded by Sexton ${ }^{(50)}$ and more than $0.31-28$; $1.39-13.91$ and $0.5-58.6 \mu \mathrm{g} / \mathrm{m}^{3}$ measured by Gustafson; Kuntasal and Schlink, respectively ${ }^{(51-53)}$. 
On the other hand this concentration is less than the annual mean concentration (Arithmetic mean) $247 \mu \mathrm{g} / \mathrm{m}^{3}$ recorded by Järnström in Finland ${ }^{(55)} ; 0.1$ - $99.3 \mu \mathrm{g} / \mathrm{m}^{3}$ reported by Kim ${ }^{(16)} ; 143 \mu \mathrm{g} / \mathrm{m}^{3}$ measured by Langer and Bekö in Sweden ${ }^{(56)} ; 138 \mu \mathrm{g} / \mathrm{m}^{3}$ measured by Rehwagen in Germany ${ }^{(57)}$; $202 \mu \mathrm{g} / \mathrm{m}^{3}$ recorded by Raw in England (measured in bedrooms) ${ }^{(58)} ; 0.2-159 \mu \mathrm{g} / \mathrm{m}^{3}$ measured by Sinha ${ }^{(59)} ; 123 \mu \mathrm{g} / \mathrm{m}^{3}$ average concentration for 53 VOCs recorded by Jia in southeast Michigan, USA ${ }^{(25)}$ and 2-137 $\mu \mathrm{g} / \mathrm{m}^{3}$ recorded by Hamidin in residential indoor air of Brisbane, Australia $^{(22)}$.

TABLE 8. Comparison between annual mean concentration of individual indoor VOCs in this study and in other literatures.

\begin{tabular}{|c|c|c|c|c|c|c|c|}
\hline & & $\underset{(54)}{\text { Gallego }}$ & $\begin{array}{l}\text { Jia } \\
(25)\end{array}$ & $\underset{\text { (22) }}{\text { Hamidin }}$ & $\underset{(7)}{\operatorname{Demirel}}$ & \begin{tabular}{|c|}
$\underset{(49)}{\text { Maisey }}$ \\
median \\
concentration
\end{tabular} & $\begin{array}{c}\text { Present } \\
\text { study } \\
\text { annual mean } \\
\text { concentration } \\
\text { of all sites }\end{array}$ \\
\hline 1 & Benzene & 0.49-8.7 & 2.84 & 2.4 & 2.29 & BDL & 7.32 \\
\hline 2 & Toluene & $\begin{array}{l}14.4- \\
50.9\end{array}$ & 15.56 & 10.7 & 26.55 & 2.62 & 5.92 \\
\hline 3 & Ethylbenzene & $1.84-8.8$ & 2.17 & 1.9 & 0.73 & 0.2 & 6.97 \\
\hline 4 & m-Xylene & $3.47-30$ & 7.93 & 3.7 & 1.13 & 0.42 & 8.83 \\
\hline 5 & Styrene & $0.22-1.5$ & 0.5 & 1.5 & - & 0.07 & 2.10 \\
\hline 6 & Bromobenzene & - & 0.01 & - & - & - & 3.42 \\
\hline 7 & $\begin{array}{c}1,3,5 \\
\text { Trimethylbenzene }\end{array}$ & n.d.-2.2 & 0.93 & - & - & - & 4.62 \\
\hline 8 & $\begin{array}{c}1,2,4 \\
\text { Trimethylbenzene }\end{array}$ & 1.3-3.9 & 3.07 & - & - & 0.32 & 1.68 \\
\hline 9 & $\begin{array}{c}\text { m- } \\
\text { Isopropyltoluene }\end{array}$ & - & & - & - & - & 5.61 \\
\hline 10 & n- Butylbenzene & - & 0.25 & - & - & - & 0.56 \\
\hline 11 & $\begin{array}{c}1,2,4 \\
\text { Trichlorobenzene }\end{array}$ & - & & - & - & - & 1.38 \\
\hline 12 & Naphthalene & $\begin{array}{l}0.01- \\
0.05\end{array}$ & 3.49 & 2.3 & - & - & 1.84 \\
\hline 13 & $\begin{array}{c}1,2.3 \\
\text { Trichlorobenzene }\end{array}$ & - & - & - & - & - & 1.45 \\
\hline
\end{tabular}

Egypt. J. Chem. 58, No. 2 (2015) 


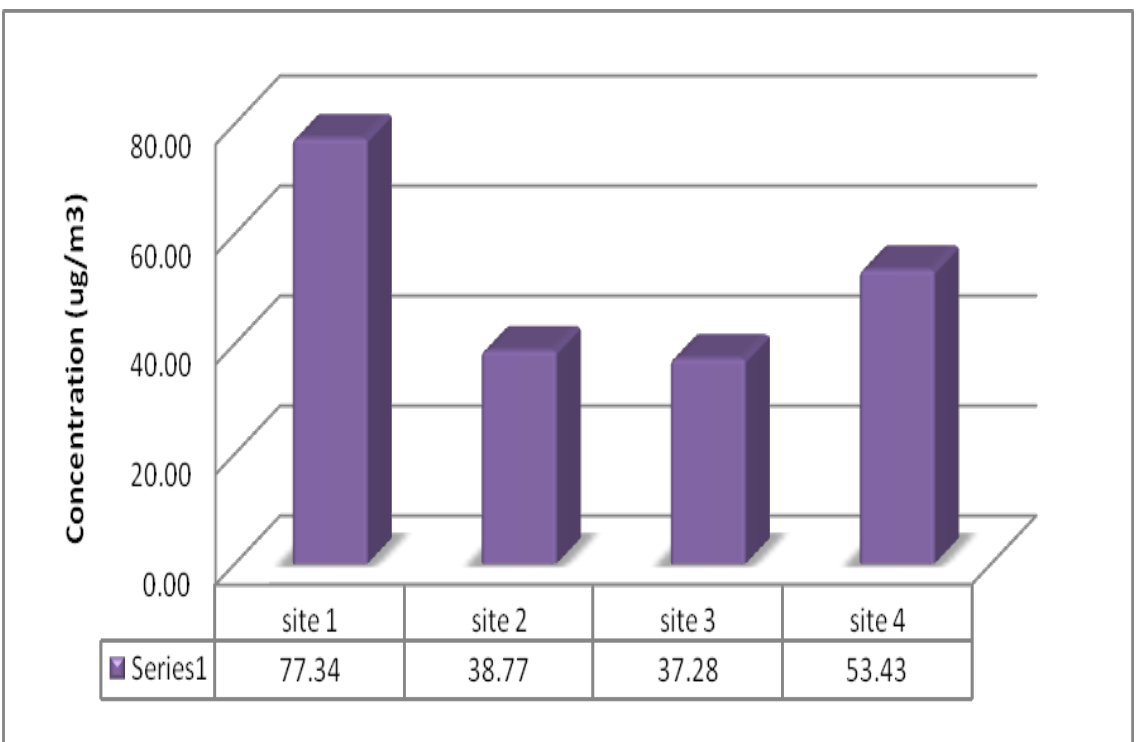

Fig. 4. Annual mean concentrations of total volatile organic compounds (VOCs) $\left(\mu \mathrm{g} / \mathrm{m}^{3}\right)$ in indoor air at sites under investigation.

\section{Seasonal variation of VOCs in indoor air}

Figure 5 showed seasonal variation of the mean concentrations of total volatile organic compounds. The maximum seasonal concentrations were recorded during winter season, while the lower seasonal concentrations of total volatile organic compounds were recorded during summer at almost all of sites under investigation. Concentrations are tending to increase in cold weather, mainly due to lower ventilation and air exchange rates ${ }^{(57)}$. In winter season, door and windows are not opened as much as in summer and spring seasons ${ }^{(60)}$. Cooler temperatures slow the rates of photochemical reactions with a simultaneous increase in the emissions from heating sources which could be a reason of the elevated VOCs concentration ${ }^{(29)}$.

The maximum concentration of VOCs was found during winter at site 1 $\left(161.7 \mu \mathrm{g} / \mathrm{m}^{3}\right)$, which may be attributed to the presence of smoker and the lower ventilation during winter at this site. However, it is lower than that recorded by Raw in English residences $\left(208 \mu \mathrm{g} / \mathrm{m}^{3}\right)$ during winter season ${ }^{(58)}$.

\section{BTEX concentration ratio}

Table 9 shows comparison between diagnostic ratios of indoor VOCs in the investigated sites and in previous studies. The maximum annual mean concentration ratios of $(\mathrm{T} / \mathrm{B})$ and $(\mathrm{m}-\mathrm{X} / \mathrm{B})$ were found at site 1 , while the maximum $(\mathrm{m}-\mathrm{X} / \mathrm{E})$ ratios were found at site 4 . $(\mathrm{T} / \mathrm{B})$ and $(\mathrm{m}-\mathrm{X} / \mathrm{B})$ annual mean concentration ratios in outdoor air of site 1 were the maximum too; which may indicate that the indoor of site 1 may be affected by outdoor pollutants sources. 

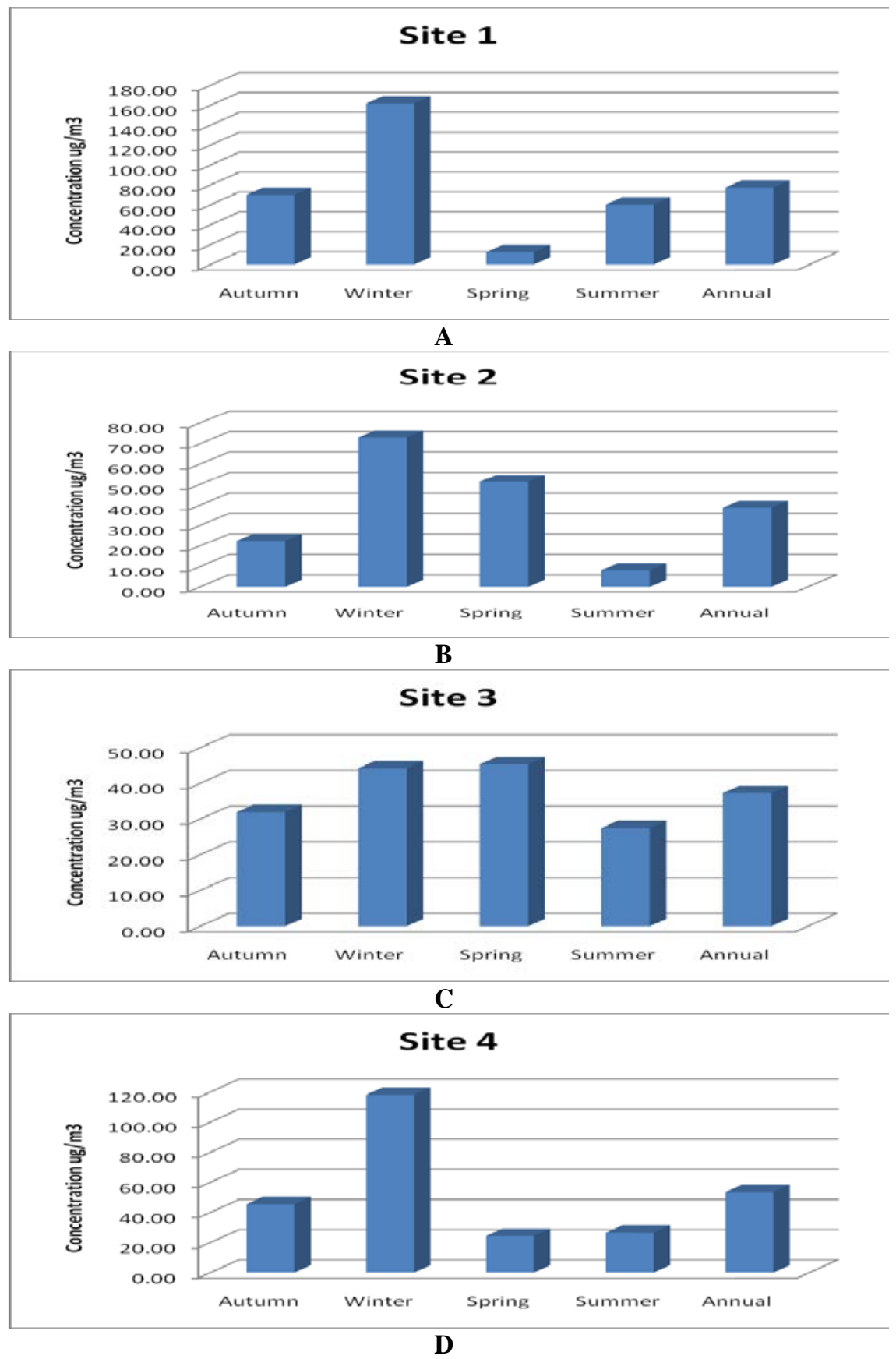

Fig.5. Seasonal and annual mean concentrations of total volatile organic compounds (VOCs) $\left(\mu \mathrm{g} / \mathrm{m}^{3}\right)$ in indoor air of sites under investigation.

Egypt. J. Chem. 58, No. 2 (2015) 


\section{BTEX correlations}

There were excellent positive correlations $(\mathrm{p}<0.001)$ between the concentrations of Benzene with the concentration of Ethylbenzene; and for Toluene with $\mathrm{m}$-Xylene at site 1 (Table 10). Site 2 showed significant positive correlations $(\mathrm{p}<0.001)$ between the concentrations of Benzene with Toluene; and for Ethylbenzene with m-xylene. which suggest that these VOCs at site 2 are originated from the same source. There were excellent positive correlations $(\mathrm{p}<0.001)$ between the concentrations of Benzene with the concentration of mXylene; and for Ethylbenzene with m-Xylene at site 4, which may indicate that they are originated from the same source.

TABLE 9. Comparison between diagnostic ratios of indoor VOCs in this study and in other studies.

\begin{tabular}{|c|c|c|c|c|c|}
\hline Country & $\begin{array}{c}\text { Area } \\
\text { characteristic }\end{array}$ & \multicolumn{3}{|c|}{ Ratio } & Reference \\
\hline & & T/B & X/B & X/EB & \\
\hline Egypt, & Site 1 & 4.97 & 3.30 & 0.84 & Present study \\
\hline Egypt, & Site 2 & 0.12 & 0.36 & 0.90 & Present study \\
\hline Egypt, & Site 3 & 0.87 & 1.67 & 1.33 & Present study \\
\hline Egypt, & Site 4 & 0.40 & 1.55 & 2.50 & Present study \\
\hline Japan & Industrial & 4.5 & 2.7 & 1.24 & (34) \\
\hline Japan & Urban & 4.8 & 1.9 & 1.13 & (34) \\
\hline Taiwan & Urban & 9.49 & 1.11 & 0.6 & (61) \\
\hline Taiwan & Industrial & 14.2 & 0.92 & 0.38 & (61) \\
\hline Taiwan & Industrial & 2.3 & 4.05 & 1.3 & (40) \\
\hline Japan & summer Industrial & 7.7 & 1.61 & 1.16 & (62) \\
\hline Japan & winter Industrial & 5.74 & 1.15 & 0.94 & (62) \\
\hline Italy & Industrial & 3.6 & 1.1 & NA & (42) \\
\hline China & Urban & 1.27 & 1.17 & 4.68 & (43) \\
\hline Turkey & Urban & 1.59 & 1.09 & 2.22 & (44) \\
\hline
\end{tabular}


TABLE 10. Correlation coefficients (r) between individual indoor BTEX at sites under investigation.

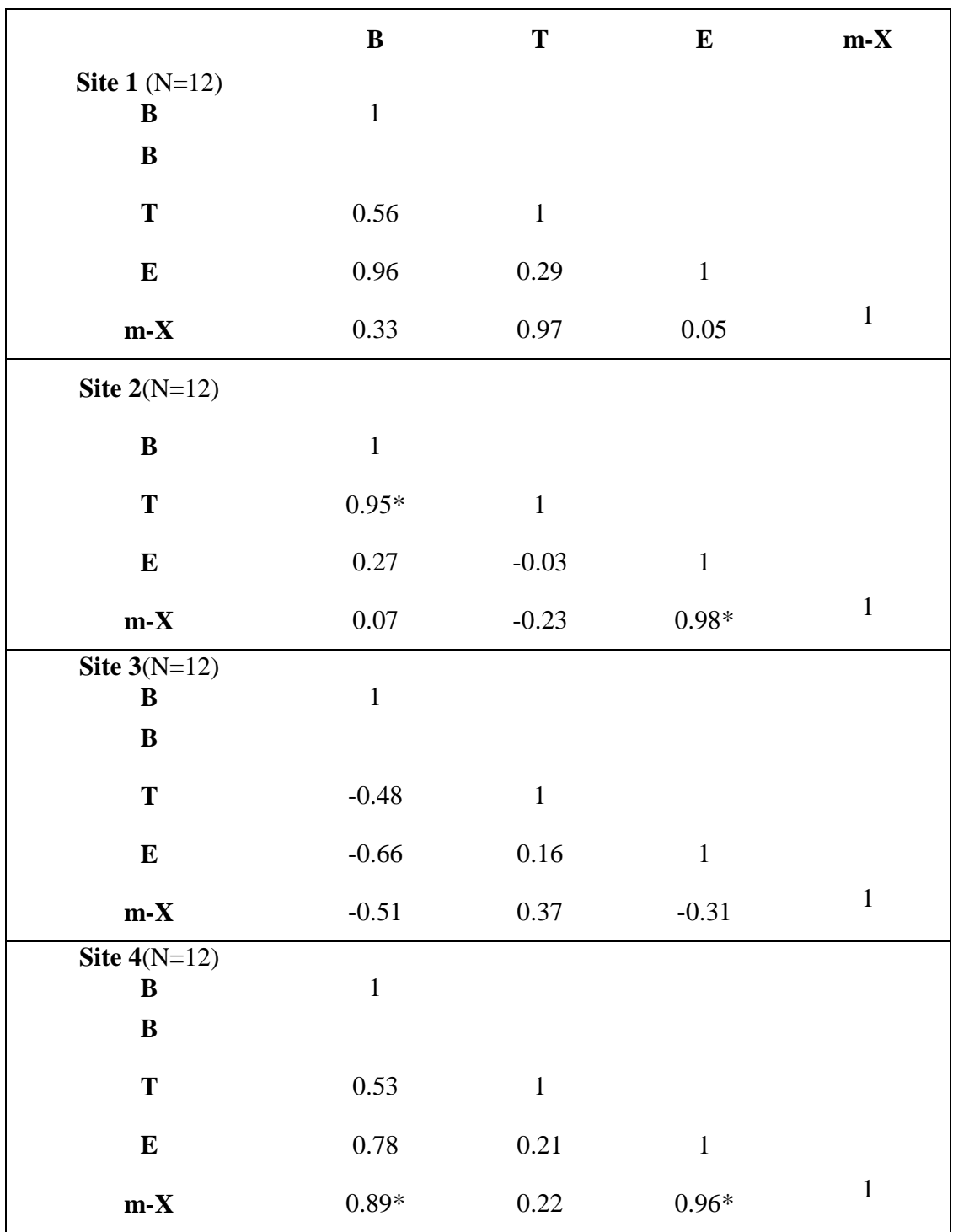

$\mathrm{N}$ : number of samples in statistical analysis.

*Significant $(\mathrm{p}<0.001)$

Difference in concentration of VOCs in indoor air of the investigated sites

Table 11 shows the difference in concentration of VOCs in indoor air of the investigated sites (between sites). As seen from this table, there was a significant difference between site 1 and sites 2 and 3 .

Egypt. J. Chem. 58, No. 2 (2015) 
TABLE 11. Difference in concentration of VOCs in indoor air of the investigated sites (between sites) .

\begin{tabular}{|c|c|c|c|c|}
\hline & site 1 & site 2 & site 3 & site 4 \\
\hline site 2 & $0.05^{*}$ & 0.5 & & \\
\hline site 3 & $0.03^{*}$ & 0.4 & 0.5 & \\
\hline site 4 & 0.15 & 0.2 & 0.1 & 0.5 \\
\hline
\end{tabular}

Table 12 shows difference in concentration of VOCs between seasons in indoor air of the investigated sites, there was significant difference between winter and all other seasons at site 1 , while there was significant difference between summer and all other seasons at site 2, also there was significant difference between winter season and all other seasons at site 4 .

TABLE 12. Difference in concentration of VOCs in indoor air of the investigated sites (between seasons) .

\begin{tabular}{|c|c|c|c|c|}
\hline & Autumn & Winter & Spring & Summer \\
\hline Autumn & 0.5 & & & \\
\hline Winter & $0.08^{*}$ & 0.5 & & \\
\hline Spring & $0.03^{*}$ & $0.005^{* * *}$ & 0.5 & \\
\hline Summer & 0.4 & $0.09^{*}$ & 0.1 & 0.5 \\
\hline
\end{tabular}

Site 1

\begin{tabular}{|c|c|c|c|c|}
\hline & Autumn & Winter & Spring & Summer \\
\hline Autumn & 0.5 & & & \\
\hline Winter & 0.1 & 0.5 & & \\
\hline Spring & 0.1 & 0.3 & 0.5 & \\
\hline Summer & $0.02^{*}$ & $0.06^{*}$ & $0.02^{*}$ & 0.5 \\
\hline
\end{tabular}

Site 2

\begin{tabular}{|c|c|c|c|c|}
\hline & Autumn & Winter & Spring & Summer \\
\hline Autumn & 0.5 & & & \\
\hline Winter & 0.2 & 0.5 & & \\
\hline Spring & 0.2 & 0.4 & 0.5 & \\
\hline Summer & 0.3 & 0.2 & 0.1 & 0.5 \\
\hline
\end{tabular}

Site 3

\begin{tabular}{|c|c|c|c|c|}
\hline & Autumn & Winter & Spring & Summer \\
\hline Autumn & 0.5 & & & \\
\hline Winter & $0.04^{*}$ & 0.5 & & \\
\hline Spring & 0.1 & $0.01^{* *}$ & 0.5 & \\
\hline Summer & 0.1 & $0.01^{* *}$ & 0.4 & 0.5 \\
\hline
\end{tabular}

Site 4

* $\quad$ Significant at $\mathrm{P}<0.05$

** Significant at $\mathrm{P}<0.01$

*** Significant at $\mathrm{P}<0.005$ 
Indoor/outdoor relationship

The indoor/outdoor VOC concentration ratio gives an idea about VOCs sources. Indoor/outdoor ratios near unity $(1 \pm 0.5)$ indicate that VOCs rise primarily from outdoor sources; ratios from about 1.5 to 10 indicate the impact of both indoor and outdoor sources. Ratios exceeding about 10 reveal primarily or exclusively indoor sources ${ }^{(25,60)}$.

From Table 13 and Fig. 7 it can be observed that the indoor annual mean concentration of total VOCs is higher than outdoor at sites 1 and 4; I/O ratios are more than 1.5 and less than 10 at these sites which indicate the effect of both indoor and outdoor sources on the indoor air at these sites; this is in agreement with Jia and Aslan ${ }^{(25,60)}$. I/O ratios at sites 2 and 3 were lower than 1 , indicating the effect of outdoor sources on the indoor air. Indoor/outdoor ratios for individual VOCs as seen from Fig. 6 varied from 1 to 10 for most VOCs, however these ratios were 10.34 and 14.33 , at site 1 , for toluene and $1,3,5$ Trimethylbenzene, respectively.

TABLE 13. Ratio between indoor and outdoor (I/O) VOCs annual mean concentrations at sites under investigation.

\begin{tabular}{|c|c|c|c|c|c|}
\hline \multicolumn{2}{|c|}{ VOCs } & Site 1 & Site 2 & Site 3 & Site 4 \\
\hline $\mathbf{1}$ & Benzene & 1.15 & 1.39 & 0.18 & 0.99 \\
\hline $\mathbf{2}$ & Toluene & 10.34 & 0.31 & 0.80 & 1.69 \\
\hline $\mathbf{3}$ & Ethylbenzene & 1.10 & 0.35 & 2.08 & 1.99 \\
\hline $\mathbf{4}$ & m-Xylene & 1.22 & 0.27 & 1.17 & 4.37 \\
\hline $\mathbf{5}$ & Styrene & 1.01 & 0.09 & 6.67 & 3.09 \\
\hline $\mathbf{6}$ & Bromobenzene & 3.59 & 0.08 & 0.78 & 3.04 \\
\hline $\mathbf{7}$ & $\mathbf{1 , 3 , 5}$ Trimethylbenzene & 14.33 & 0.52 & 0.50 & 2.63 \\
\hline $\mathbf{8}$ & $\mathbf{1 , 2 , 4}$ Trimethylbenzene & 1.78 & 0.40 & 0.64 & 2.81 \\
\hline $\mathbf{9}$ & $\mathbf{m}$ - Isopropyltoluene & 2.11 & 0.97 & 9.65 & 4.40 \\
\hline $\mathbf{1 0}$ & n- Butylbenzene & 0.81 & 0.41 & 0.31 & 1.65 \\
\hline $\mathbf{1 1}$ & $\mathbf{1 , 2 . 4}$ Trichlorobenzene & 0.09 & 0.22 & 2.25 & 0.54 \\
\hline $\mathbf{1 2}$ & Naphthalene & 0.39 & 0.35 & 0.94 & 0.76 \\
\hline $\mathbf{1 3}$ & $\mathbf{1 , 2 . 3}$ Trichlorobenzene & 0.50 & 0.14 & 0.14 & 3.11 \\
\hline & Annual Mean & $\mathbf{1 . 5 5}$ & $\mathbf{0 . 3 7}$ & $\mathbf{0 . 7 1}$ & $\mathbf{1 . 9 8}$ \\
\hline
\end{tabular}

Egypt. J. Chem. 58, No. 2 (2015) 


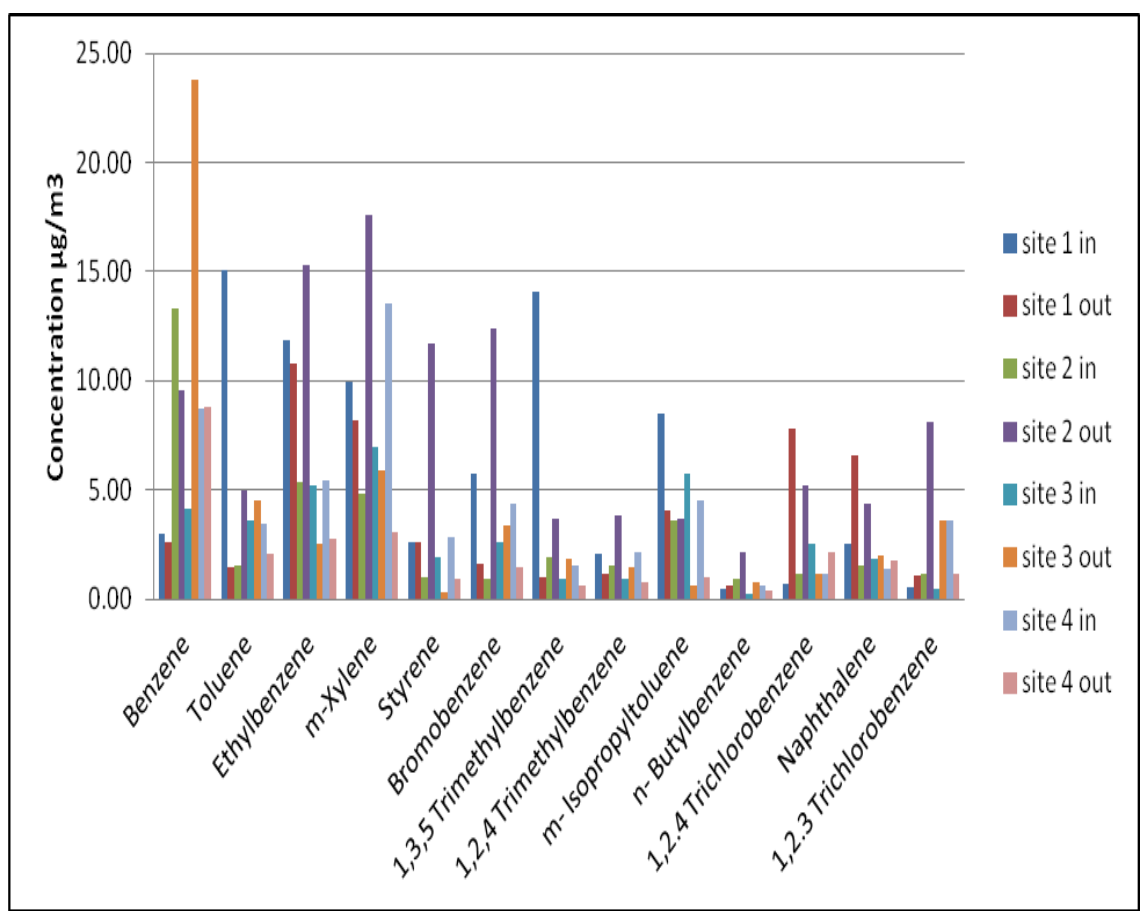

Fig. 6. Comparison between indoor and outdoor individual VOCs annual mean concentrations in $\mathbf{4}$ sites under investigation .

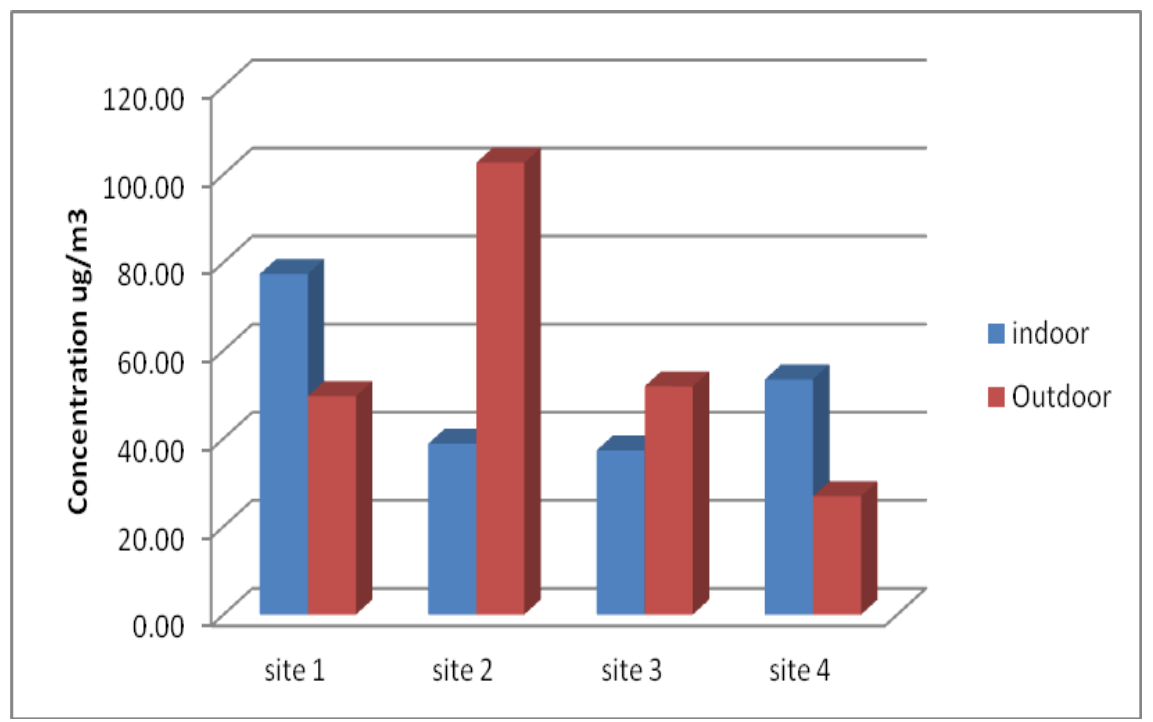

Fig. 7. Comparison between indoor and outdoor total VOCs annual mean concentrations at sites under investigation.

Egypt. J. Chem. 58, No. 2 (2015) 


\section{Conclusions}

Information regarding concentrations of indoor volatile organic compounds (VOCs) in Egypt is limited in terms of the number and types of the measured compounds. This study characterizes thirteen volatile organic compounds (13 VOCs) inside and outside of four residential sectors of Helwan city, south Cairo, Egypt during four seasons that represent a gradient of population density and affected by nearby emissions of industrial activity, and also to identify indoor/outdoor relationships. Monitoring was conducted in one year (starting from September 2010 to August 2011). The most abundant VOCs compounds in ambient air at area under investigation as annual mean concentration were Benzene, mXylene, Ethylbenzene, Bromobenzene, 1,2.4 Trichlorobenzen and Styrene. Concentrations were elevated in winter. Meanwhile, the most abundant indoors VOCs compounds as annual mean concentration were m-Xylene, Benzene, Ethylbenzene and Toluene. Indoor/outdoor ratios (I/O ratio) for annual mean concentration of individual VOCs varied from 1 to 10 for most compounds, and up to 10.34 and 14.33 at site 1 for toluene and 1,3,5 trimethylbenzene, respectively, which indicates that the air inside Egyptian homes is affected by both indoor and outdoor sources. The study shows the importance of both indoor and outdoor sources on the concentration of indoor VOCs.

\section{References}

1. Klepeis, N.E., Nelson, W.C., Ott, W.R., Robinson, J.P., Tsang, A.M., Switzer, P., Behar, J.V., Hern, S.C. and Engelmann, W.H., The national human activity pattern survey (NHAPS): a resource for assessing exposure to environmental pollutants. J. Exposure Analysis and Environ. Epidemi. 11, 231 (2001).

2. Stathopoulou, O. I. and Assimakopoulos, V. D., Numerical study of the indoor environmental conditions of a large Athletic Hall using the CFD code PHOENICS'. Environ Model Assess. (2006).

3. Whitworth, K.W., Symanski, E. and Coker, A.L., Childhood lympho hematopoietic cancer incidence and hazardous air pollutants in southeast Texas, 1995-2004. Environ. Health Perspect. 116, 1576 (2008).

4. WHO (World Health Organization), Selected pollutants. WHO indoor air quality guidelines. Copenhagen: WHO Regional Office for Europe;. p. 1-454 (2010). http://www.euro.who.int/ data/assets/pdf file/0009/128169/-94535.pdf.

5. Pickett, A.R. and Bell, M.L., Assessment of indoor air pollution in homes with infants. Int. J. Environ. Res. Public Health, 8, 4502 (2011).

6. Lu, H., Amagai, T. and Ohura, T., Comparison of polycyclic aromatic hydrocarbon pollution in Chinese and Japanese residential air. Journal of Environmental Sciences, 23(9), 1512-1517 (2011). 
7. Demirel, G., Özden, O., Döğeroğlu,T. and Gaga, E.O., Personal exposure of primary school children to BTEX, $\mathrm{NO}_{2}$ and ozone in Eskişehir, Turkey: Relationship with indoor/outdoor concentrations and risk assessment. Science of the Total Environment, 473, 537 (2014).

8. Gao, Y., Zhang, Y., Kamijima, M., Sakai, K., Khalequzzaman, M., Nakajima, T., Shi, R., Wang, X., Chen, D., Ji, X., Han, K. and Tian, Y., Quantitative assessments of indoor air pollution and the risk of childhood acute leukemia in Shanghai. Environmental Pollution, 187,81(2014).

9. Onyinyechukwu, N., Measurement of indoor air pollution by volatile organic compounds (VOCs) In NW1 building University of Bremen. Master Degree of Science in Environmental Physics. Faculty of Physics and Electrical Engineering. University of Bremen (2008).

10. WHO (World Health Organisation), Indoor air quality: organic pollutants. WHO Regional Office for Europe (EURO Reports and Studies No. 111), Copenhagen (1989).

11. USEPA, Reducing Risk: Setting Priorities and Strategies for Environmental Protection. U.S. Environmental Protection Agency (1990).

12. Wei, W., Xiong, Z., Zhao, W. and Zhang, Y., A framework and experimental study of an improved Department VOC/formaldehyde emission reference for environmental chamber tests. Atmo. Environ. 82, 327 (2014).

13. Baya, M.P., Bakeas, E.B. and Siskos, P.A., Volatile organic compounds in the air of 25 Greek homes. Indoor and Built Enviro. 13, 53 (2004).

14. WHO (World Health Organization), Particulate Matter, Chapter 7.3. WHO Regional Publications, European Series, Copenhagen, Denmark, 1-40 (2000).

15. Bohm, M., Salem, M.Z.M. and Srba, J., Formaldehyde emission monitoring from a variety of solid wood, plywood, blockboard and flooring products manufactured for building and furnishing materials. J. Hazard. Mater. 211, 68 (2012).

16. Kim, Y.M., Harrad, S. and Harrison, R.M., Concentrations and sources of VOCs in urban domestic and public microenvironments. Environ. Sci. and Tech. 35, 997 (2001).

17. Hinwood, A.L., Rodriguez, C., Runnion, T., Farrar, D., Murray, F. and Horton, A., Risk factors for increased BTEX in four Australian cities. Chemosphere, 66, 533 (2007).

18. Auvinen, J. and Wirtanen, L., The influence of photocatalytic interior paints on indoor air quality. Atmo. Enviro. 37, 4101 (2008).

19. OEHHA, California's Office of Environmental Health Hazard Assessment (2007). http://www.oehha.ca.gov/air.html. 
20. Census, Central Agency for Public Mobilisation and Statistics, Population and Housing Census, Population distribution by sex, gov: Cairo Retrieved on 200604-01 (2006).

21. NIOSH, Method 2549 in the NIOSH Manual of Analytical Methods, fourth ed. US Department of Health and Human Services, Center for Disease Control, NIOSH; Cincinnati, OH. May 15 (1996).

22. Hamidin, N., Yu, J., Phung, D.T., Connell, D. and Chu, C., Volatile aromatic hydrocarbons (VAHs) in residential indoor air in Brisbane, Australia. Chemosphere, 92, 1430 (2013).

23. Parra, M.A., Elustondo, D., Bermejo, R. and Santamaría, J.M., Ambient air levels of volatile organic compounds (VOC) and nitrogen dioxide $\left(\mathrm{NO}_{2}\right)$ in a medium size city in Northern Spain. Sci. of the Total Environ. 407, 999 (2009).

24. EC Directive, 69/EC of the European Parliament and of the Council of 16 November 2000 relating to limit values for benzene and carbon monoxide in ambient air. Official Journal of the European Communities. 13 December 2000 (2000).

25. Jia, C., Batterman, S. and Godwin, C., VOCs in industrial, urban and suburban neighborhoods, Part 1: Indoor and outdoor concentrations, variation, and risk drivers. Atmos. Environ. 42, 2083 (2008).

26. Ohura, T., Amagai, T., Shen, X., Li., S., Zhang, P. and Zhu, L., Comparative study on indoor air quality in Japan and China: Characteristics of residential indoor and outdoor VOCs. Atmos. Environ. 43, 6352 (2009).

27. Park, K.-H. and Jo, W.-K., Heterogeneous photocatalysis of aromatic and chlorinated volatile organic compounds (VOCs) for non-occupational indoor air application. Chemosphere, 57, 555 (2004).

28. Liu, P.W.G., Yao, Y.C., Tsai, J.H., Hsu, Y.C., Chang, L.P. and Chang, K.H., Source impacts by volatile organic compounds in an industrial city of southern Taiwan. Sci. Total Environ. 398,154 (2008a).

29. Mohamed, M., Kang, D. and Aneja, V., Volatile organic compounds in some urban locations in United States. Chemosphere, 47, 863 (2002).

30. Batterman, S.A., Peng, C.Y. and Braun, J., Levels and composition of volatile organic compounds on commuting routes in Detroit, Michigan. Atmos Environ. 36, 6015 (2002).

31. Kourtidis, K.A., Ziomas, I., Zerefos, C., Kosmidis, E., Symeonidis P. and Christophilopoulus, E., Benzene, toluene, ozone, $\mathrm{NO}_{2}$ and $\mathrm{SO}_{2}$ measurements in an urban street canyon in Thessaloniki, Greece. Atmos. Environ. 36, 5355 (2002). 
32. Pankow, J.F., Luo, W., Bender, D.A., Isabelle, L.M., Hollingsworth, J.S. and Chen, C., Concentrations and co-occurrence correlations of 88 volatile organic compounds (VOCs) in the ambient air of 13 semi-rural to urban locations in the Unites States. Atmos. Environ. 37, 5023 (2003).

33. Lee, C.W., Dai, Y.T., Chien, C.H. and Hsu, D.J., Characteristics and health impacts of volatile organic compounds in photocopy centers. Environ. Research. 100, 139 (2006).

34. Tiwari, V., Hanai, Y. and Masunaga, S., Ambient levels of volatile organic compounds in the vicinity of petrochemical industrial area of Yokohama, Japan. Air Qual. Atmos. Health. 3, 65 (2010).

35. Ho, K.F., Lee, S.C., Guo, H. and Tsai, W.Y., Seasonal and diurnal variations of volatile organic compounds (VOCs) in the atmosphere of Hong Kong. Science of the Total Environ. 322, 155 (2004).

36. Guo, H., So, K.L., Simpson, I.J., Barletta, B., Meinardi, S. and Blake, D.R., C1C8 volatile organic compounds in the atmosphere of Hong Kong: overview of atmospheric processing and source apportionment. Atmos. Environ. 41, 1456 (2007).

37. Kerbachi, R., Boughedaoui, M., Bounoua, L. and Keddam, M., Ambient air pollution by aromatic hydrocarbons in Algiers. Atmos. Environ. 40, 3995 (2006).

38. Derwent, R.G., Davies, T.J., Delaney, M., Dollard, G.J., Field, R.A. and Dumitrean, P., Analysis and interpretation of the continuous hourly monitoring data for 26 C2-C8 hydrocarbons at 12 United Kingdom sites during 1996. Atmos. Environ. 34, 297 (2000).

39. Monod, A., Sive, B.C., Avino, P., Chen, T., Blake, D.R. and Rowland, F.S., Monoaromatic compounds in ambient air of various cities: a focus on correlations between the xylenes and ethylbenzene. Atmos. Environ. 35, 135 (2001).

40. Chang, C.C., Sree, U., Lin, Y.S. and Lo, J.G., An examination of 7:00- 9:00 pm ambient air volatile organics in different seasons of Kaohsiung city, southern Taiwan. Atmos. Environ. 39, 867 (2005).

41. Ohura, T., Amagai,T., Senga, Y. and Fusaya, M., Organic air pollutants inside and outside residences in Shimizu, Japan: Levels, sources and risks. Science of the Total Enviro. 366, 485 ( 2006).

42. Gariazzo, C., Pelliccioni, A., Di Filippo, P., Sallusti, F. and Cecinato, A., Monitoring and analysis of volatile organic compounds around an oil refinery. Water Air Soil Pollut. 167, 17 (2005).

43. Wang, X.M., Sheng, G.Y., Fum, J.M., Chan, C.Y., Lee, S.C., Chan, L.Y. and Wang, Z.S., Urban roadside aromatic hydrocarbons in three cities of the Pearl River Delta, People’s Republic of China. Atmos. Environ. 36, 5141 (2002).

44. Muezzinoglu, A., Odabasi, M. and Onat, L., Volatile organic compounds in the air of Izmir, Turkey. Atmos. Environ. 35, 753 (2001).

Egypt. J. Chem. 58, No. 2 (2015) 
45. Khoder, M.I., Ambient levels of volatile organic compounds in the atmosphere of Greater Cairo. Atmos. Environ. 41, 554 (2007).

46. Brown, S.K., Volatile organic pollutants in new and established buildings in Melbourne, Australia. Indoor Air. 12, 55 (2002).

47. Son, B., Breysse, P. and Yang, W., Volatile organic compounds concentrations in residential indoor and outdoor and its personal exposure in Korea. Environ. International. 29, 79 (2003).

48. Destaillats, H. et al., Indoor pollutants emitted by office equipment. A review of reported data and information needs. Atmos. Environ. 42, 1371 (2008).

49. Maisey, S.J., Saunders , S.M., West, N. and Franklin, P.J., An extended baseline examination of indoor VOCs in a city of low ambient pollution: Perth, Western Australia. Atmos. Environ. 81, 546 (2013).

50. Sexton, K., Adgate, J.L., Ramachandran, G., Pratt, G.C., Mongin, S.J., Stock, T.H. and Morandi, M.T., Comparison of personal, indoor, and outdoor exposures to hazardous air pollutants in three urban communities. Environ. Sci. Technol. 38, 423 (2004).

51. Gustafson, P., Barregard, L., Strandberg, B. and Sällsten, G., The impact of domestic wood burning on personal, indoor and outdoor levels of 1,3-butadiene, benzene, formaldehyde and acetaldehyde. J. Environ. Monit. 9, 23 (2007).

52. Kuntasal, O.O., Karman, D., Wang, S.G., Tuncel, S.G. and Tuncel, G., Detrmination of volatile organic compounds in different microenvirnments by multibed absorption and short - path thermal desorption followed by gas chromatographic - mass spectrometric analysis. J. Chromatogr. A. 1099, 43 (2005).

53. Schlink, U., Rehwagen, M., Damm, M., Richter, M., Borte, M. and Herbarth, O., Seasonal cycle of indoor-VOCs: comparison of apartments and cities. Atmos. Environ. 38, 1181 (2004).

54. Gallego, E., Roca, X., Perales, J.F. and Guardino, X., Determining indoor air quality and identifying the origin of odour episodes in indoor environments. Journal of Environ. Sciences. 21, 333 (2009).

55. Järnström, H., Saarela, K., Kalliokoski, P. and Pasanen A.L., Reference values for indoor air pollutant concentrations in new, residential buildings in Finland. Atmos. Environ. 40,7178 (2006).

56. Langer, S. and Bekö, G., Indoor air quality in the Swedish housing stock and its dependence on building characteristics. Building and Environ. 69, 44 (2013).

57. Rehwagen, M., Schlink, U. and Herbarth, O., Seasonal cycle of VOCs in apartments. Indoor Air. 13, 283 (2003). 
58. Raw, G.J., Coward, S.K.D., Brown, V.M. and Crump, D., Exposure to air pollutants in English residences. Journal of Exposure Analysis and Environ. Epidem. 14(Suppl.), S85-S94 (2004).

59. Sinha, S.N., Kulkarni, P.K., Shah, S.H., Desai, N.M., Patel, G.M., Mansuri, M.M. and Saiyed, H.N., Environmental monitoring of benzene and toluene produced in indoor air due to combustion of solid biomass fuels. Science of the Total Environ. 357, 280 (2006).

60. Aslan, G., Monitoring and assessment of indoor air volatile organic compound concentrations in primary schools. Master degree of science, School of Engineering and Sciences of Izmir, Institute of Technology (2008).

61. Liu, Y., Shao, M., Fu, L., Lu, S., Zeng, L. and Tang, D., Source profiles of volatile organic compounds (VOCs) measured in China: part I. Atmos. Environ.42, 6247 (2008b).

62. Ohura T., Amagai T. and Fusaya M., Regional assessment of ambient volatile organic compounds in an industrial harbor area, Shizuoka, Japan. Atmos Environ. 40, 238 (2006a).

(Received 15/2/2015;

accepted 25/3/2015) 


\section{مستويات المركبات العضوية المتطايرة داخل وخارج المنازل بمدينة حلوان - مصر المر اتعر}

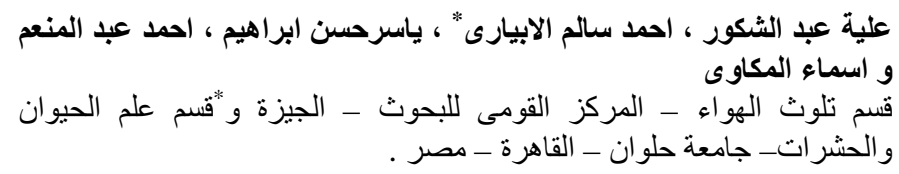

قامت هذه الدر اسة بقياس المركبات العضوية المتطايرة فى الهواء داخل و خارج

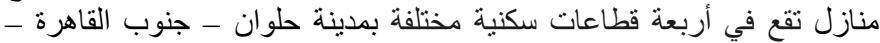

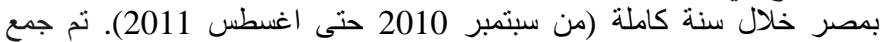
عينات المركبات العضوية المتطايرة وفقا للطريقة القياسية التي وضتئية

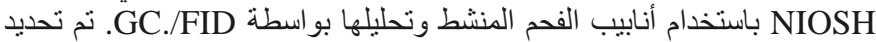

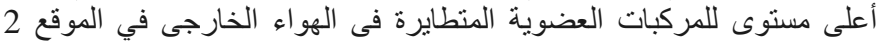

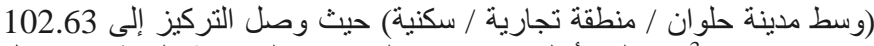

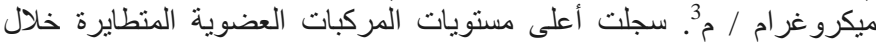
فصلى الثتاء و الخريف، في حين تم قياس أدنى القيم في الصيف.

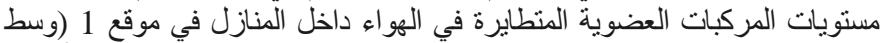

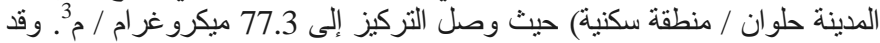

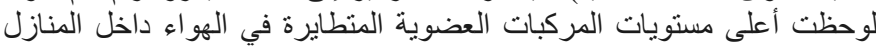

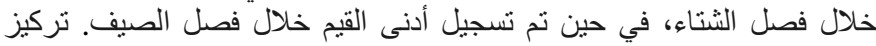

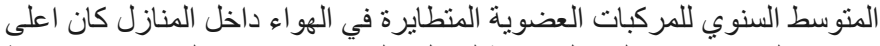

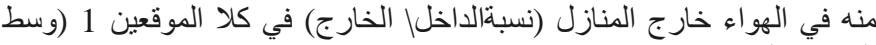

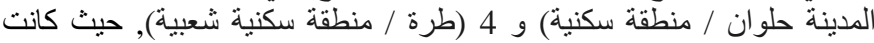

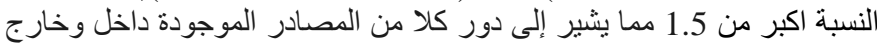

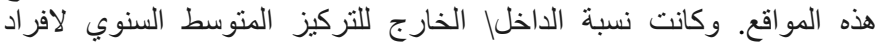

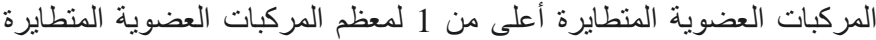

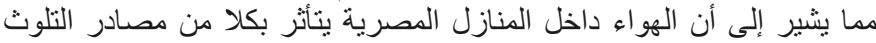

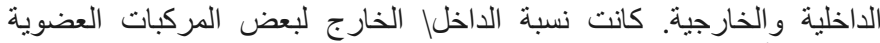

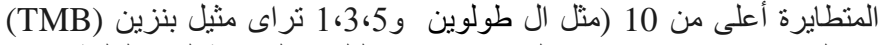

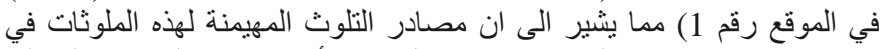

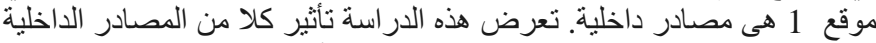

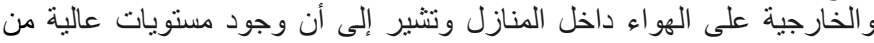
المركبات العضوية المنطايرة داخل هذه المنازل كافية لتشئل التشكل خطر على السكان

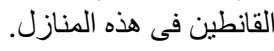

